\title{
Isolasi dan Produktivitas Bakteri Ureolitik dari Sedimen Muara Sungai Citarum
}

\section{Isolation and Productivity of Ureolytic Bacteria from Citarum River Estuary Sediments}

\author{
HANIES AMBARSARI ${ }^{1}$, LUFTIARA ASRIYANI ${ }^{2}$, AFLAKHUR RIDLO ${ }^{3}$ \\ ${ }^{1}$ Pusat Teknologi Lingkungan, Badan Pengkajian dan Penerapan Teknologi (BPPT) \\ ${ }^{2}$ UIN Syarif Hidayatullah Ciputat Jakarta \\ ${ }^{3}$ Pusat Pengkajian Industri Proses dan Energi, Badan Pengkajian dan Penerapan Teknologi (BPPT) \\ Email: hanies.ambarsari@bppt.go.id
}

\begin{abstract}
This research carried out isolation of ureolytic bacteria taken from soil samples from the mangrove area of Muara Gembong, Citarum River. The aim was to characterize and to test the urease production activity of the ureolytic bacteria. The study was conducted at the BPPT Environmental Laboratory in Building 820 Geostech, Puspiptek Setu, South Tangerang City, Banten Province, from April until September 2019. The results showed that there were ureolytic bacterial isolates from soil samples taken. The productivity of ureolytic bacterial isolates was indicated by the increasing ammonia concentration and the increase of bacterial cell concentration supported by the $\mathrm{pH}$ and temperature factors per volume unit of $10 \mathrm{ml}$. The increase in ammonia concentration of the six isolates' test media showed significant differences. The highest increase in ammonia concentration was $15.19 \mathrm{ppm}$ produced by isolate K5A and the second highest was $14.10 \mathrm{ppm}$ by isolate K7. Another productivity testing was performed by determining if there was an increase in the concentration of bacterial cells. Based on the analysis of variance, each isolates significantly affected the increase in bacterial cell concentration. The highest increase in bacterial cell concentration by $250.45 \times 10^{6} \mathrm{CFU} / \mathrm{ml}$ occurred in isolates $\mathrm{K} 5 \mathrm{~A}$, while isolate $\mathrm{K} 7$ indicated the secondhighest increase in cell concentration by $233.31 \times 10^{6} \mathrm{CFU} / \mathrm{ml}$.
\end{abstract}

Keywords: ureolytic bacteria, productivity, mangrove sediment, Citarum River Estuary

\begin{abstract}
ABSTRAK
Penelitian ini melakukan isolasi bakteri ureolitik yang diambil dari sampel tanah dari daerah mangrove dari di Muara Gembong, Sungai Citarum. Tujuannya adalah untuk melakukan karakterisasi dan menguji aktivitas produksi urease terhadap isolat bakteri ureolitik yang ditemukan. Penelitian dilakukan di Laboratorium Lingkungan BPPT di Gedung 820 Geostech, Puspiptek Setu, Kota Tangerang Selatan, Provinsi Banten mulai bulan April sampai dengan September 2019. Enam isolat bakteri dapat diperoleh dari sampel tanah yang diambil. Produktivitas isolat bakteri ureolitik pada penelitian ini dapat ditandai dengan kenaikan konsentrasi amonia kenaikan konsentrasi sel bakteri yang didukung dengan faktor $\mathrm{pH}$ dan suhu per satuan volume $10 \mathrm{ml}$. Kenaikan konsentrasi amonia dari keenam media uji isolat menunjukkan perbedaan yang nyata. Produksi konsentrasi amonia tertinggi sebesar 15,19 ppm dihasilkan oleh isolat K5A dan tertinggi kedua sebesar $14,10 \mathrm{ppm}$ oleh isolat K7. Untuk uji produktivitas juga dilakukan dengan melihat adanya kenaikan konsentrasi sel bakteri. Berdasarkan analisis variansi, masing-masing isolat berpengaruh nyata terhadap kenaikan konsentrasi sel bakteri. Kenaikan konsentrasi sel bakteri tertinggi sebesar $250,45 \times 10^{6} \mathrm{CFU} / \mathrm{ml}$ terjadi pada isolat bakteri K5A sedangkan isolat $\mathrm{K} 7$ menunjukkan kenaikan konsentrasi sel tertinggi kedua sebesar $233,31 \times 10^{6} \mathrm{CFU} / \mathrm{ml}$.
\end{abstract}

Kata kunci: bakteri ureolitik, produktivitas, sedimen mangrove, Muara Sungai Citarum

\section{PENDAHULUAN}

\subsection{Latar Belakang}

Biogeoteknik merupakan teknologi penggunaan agen biologis terutama mikroba sebagai agen produsen eksopolisakarida untuk menghasilkan kalsium karbonat sebagai penguat struktur tanah ${ }^{(1)}$. Agen biologis yang berperan dalam proses biogeoteknik ini antara lain adalah bakteri ureolitik. Penelitian ini dilakukan untuk memperoleh bakteri ureolitik yang ada di suatu kawasan mangrove, yang salah satunya di daerah Muara Gembong, Bekasi. Pengambilan sampel di daerah sedimen mangrove dikarenakan wilayah ini merupakan daerah antara perairan air laut dan daratan yang diasumsikan tersedianya urea yang melimpah. Dengan asumsi, penggunaan pupuk berlebihan pada area persawahan yang terbawa oleh aliran air mengalir masuk ke sungai dan berakhir di 
daerah mangrove. Konsentrasi amonia yang ada pada sampel tanah persawahan dan sampel sedimen sungai Muara Gembong Bekasi secara berurutan sebesar 6,23 ppm dan 4,50 $\mathrm{ppm}^{(2,3)}$. Tersedianya urea di mangrove terjadi akibat aktivitas antropogenik yang berasal dari penggunaan pupuk pertanian dan limbah dari proses urinasi yang meningkatkan konsentrasi urea di lingkungan perairan ${ }^{(4)}$. Selain itu, berdasarkan data(5), luasan tutupan mangrove Muara Gembong hanya $6,51 \%$ atau 682,10 ha dari total kawasan hutan, sisanya telah beralih fungsi menjadi tambak, sawah, kebun dan pemukiman. Oleh karena itu, sampel sedimen mangrove dapat digunakan sebagai sumber isolasi bakteri ureolitik. Hasil penelitian ini diharapkan dapat dikembangkan untuk skala lebih besar yang dapat bermanfaat untuk biogrouting yang memperkuat struktur tanah, terutama sebagai tindakan mitigasi bencana tanah bergerak dan bencana geologis lainnya.

\subsection{Tujuan Penelitian}

Penelitian ini bertujuan untuk memperoleh bakteri ureolitik dari sampel sedimen mangrove yang berasal dari muara Sungai Citarum dan mengetahui kemampuan isolat bakteri ureolitik yang sudah diperoleh tersebut dalam memproduksi enzim urease untuk aplikasi biogrouting nantinya.

\section{BAHAN DAN METODE}

Metode penelitian ini terdiri dari beberapa tahap, yaitu persiapan alat dan bahan, pembuatan media, isolasi bakteri, purifikasi bakteri, pengamatan morfologi, pengamatan koloni dan pengukuran produktivitas bakteri dengan parameter utama adalah aktivitas urease (amonia) dan parameter pendukung, yaitu $\mathrm{pH}$, konsentrasi sel, dan suhu. Skema cara kerja dapat dilihat pada Gambar 1.

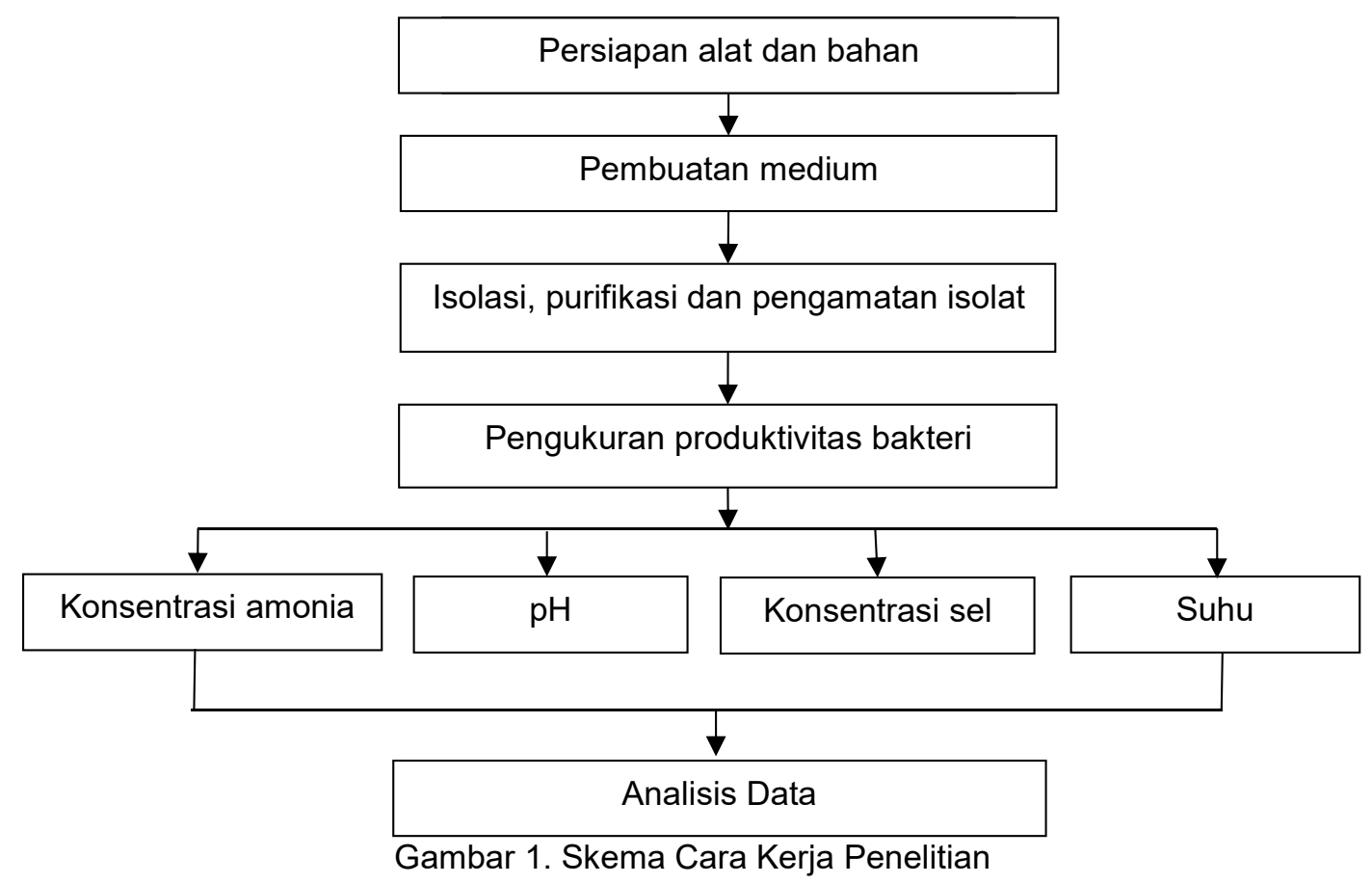

\subsection{Pembuatan Medium}

Medium urea agar base dibuat untuk mengisolasi bakteri yang dilakukan dengan cara memasukkan $1 \mathrm{~g}$ pepton, $1 \mathrm{~g}$ D-glukosa, $5 \mathrm{~g}$ natrium klorida $(\mathrm{NaCl}), 2 \mathrm{~g}$ potasium dihidrogen fosfat $\left(\mathrm{KH}_{2} \mathrm{PO}_{4}\right)$, 0,012 $\mathrm{g}$ phenol red, $15 \mathrm{~g}$ agar ke dalam $950 \mathrm{ml}$ akuades lalu dipanaskan hingga larut. Medium yang telah larut disterilisasi selama 20 menit dengan suhu $121^{\circ} \mathrm{C}$, lalu didinginkan hingga mencapai suhu $45-50{ }^{\circ} \mathrm{C}$. Medium didiamkan hingga suhu menurun lalu ditambahkan $50 \mathrm{ml}$ larutan urea $40 \%$ yang sudah disterilisasi dengan UV pada panjang gelombang $270 \mathrm{~nm}$ selama 15 menit lalu diaduk hingga rata. Proses pembuatan larutan urea dilakukan dengan cara, $40 \mathrm{~g}$ urea ditimbang lalu disterilisasi dengan sinar UV di dalam Laminar Air Flow (LAF) dengan cara diaduk-aduk setelah 30 menit agar terjadi kontak sinar UV ke permukaan urea secara merata, lalu dilarutkan dalam $100 \mathrm{ml}$ akuades steril. Sebelumnya, alat-alat yang digunakan telah dalam kondisi steril.

Medium NA-urea (Nutrien Agar-urea atau Urease Test Agar) miring dibuat untuk menyimpan stok kultur isolat yang dilakukan dengan cara ditimbang $8 \mathrm{~g}$ Nutrient Broth (NB) dan $15 \mathrm{~g}$ agar yang dilarutkan dalam $950 \mathrm{ml}$ akuades dan diaduk hingga larut. Medium yang telah larut disterilisasi selama 20 menit dengan suhu $121^{\circ} \mathrm{C}$, lalu didinginkan hingga mencapai 
suhu $45-50{ }^{\circ} \mathrm{C}$ lalu ditambahkan $50 \mathrm{ml}$ larutan urea $40 \%$ steril dan dihomogenkan.

Pembuatan medium cair (urea base) dibuat dengan komposisi dan metode yang sama dengan pembuatan medium urea agar base namun tidak ditambahkan dengan agar.

\subsection{Isolasi, Purifikasi, dan Pengamatan Isolat}

Sampel sedimen mangrove ditimbang sebanyak $1 \mathrm{~g}$ dan dimasukkan ke dalam tabung reaksi yang berisi $9 \mathrm{ml}$ larutan fisiologis $(\mathrm{NaCl}$ $0,85 \%$ ), kemudian dihomogenkan dan didapatkan pengenceran $10^{-1}$; untuk mendapatkan $10^{-2}$ dilakukan dengan cara mengambil $1 \mathrm{ml}$ larutan dari pengenceran $10^{-1}$ lalu dimasukkan ke dalam tabung reaksi yang berisi $9 \mathrm{ml}$ larutan fisiologis $(\mathrm{NaCl} 0,85 \%)$; demikian seterusnya sampai didapatkan pengenceran $10^{-6}$ secara duplo.

Sebanyak $0,1 \mathrm{ml}$ larutan dari masing-masing sampel pengenceran (mulai pengenceran 10-1 sampai dengan $10^{-6}$ ) lalu diinokulasikan dengan teknik spread plate menggunakan batang $L$ pada medium urea agar base. Setelah itu diinkubasi menggunakan inkubator Memmert dengan suhu $35{ }^{\circ} \mathrm{C}$ selama 48 jam di Laboratorium Mikrobiologi Lingkungan PTL-BPPT. Untuk koloni yang tumbuh diambil masing-masing satu koloni dengan morfologi (bentuk, tepi, elevasi, dan warna) yang berbeda dan diinokulasikan kembali ke dalam medium urea agar base dengan teknik streak plate kemudian diinkubasi pada suhu 35 ${ }^{\circ} \mathrm{C}$ selama 48 jam. Isolat yang dapat menghidrolisis urea dan mengubah medium dari kuning menjadi warna merah ungu di sekitar koloni, dianggap kandidat bakteri ureolitik untuk penelitian ini. Hal ini bertujuan untuk mengetahui kandidat bakteri yang memiliki enzim urease dan dapat menghidrolisis urea.

Seluruh isolat bakteri yang diperoleh lalu dimurnikan sampai menghasilkan isolat bakteri tunggal. Kandidat koloni tunggal dapat dilihat dari pengamatan morfologi bakteri dan pewarnaan Gram yang diamati dengan mikroskop dengan perbesaran 1.000x. Secara teori, koloni tunggal bakteri tersebut diasumsikan hanya mewakili satu strain bakteri. Bakteri tumbuh di media padat sebagai koloni. Koloni didefinisikan sebagai massa mikroorganisme yang dapat berasal dari sel induk tunggal. Hasil isolasi yang telah murni disimpan di dalam lemari es sebagai kultur stok dalam medium NA-urea miring.

Pengamatan koloni diambil dari koloni bakteri pada medium urea agar base hasil four streak plate. Guna mempermudah dan memperjelas proses pengamatan morfologi koloni, diambil 1 ose koloni muda dari hasil four streak lalu diinokulasikan ke dalam medium urea agar base yang baru dan diinkubasi pada suhu $35{ }^{\circ} \mathrm{C}$ selama 48 jam. Karakteristik yang diamati meliputi bentuk, tepi, elevasi dan warna di bawah mikroskop stereo. Pengamatan ini dilakukan dengan merujuk pada Microbiology: A laboratory manual book ${ }^{(6)}$.

Satu koloni yang terpilih pada medium urea agar base selain dilakukan pengamatan koloni juga dilakukan pengamatan sel. Pengamatan sel dilakukan dengan pewarnaan Gram dan pengamatan bentuk sel dengan menggunakan mikroskop cahaya pada perbesaran $1.000 x^{(6)}$.

\subsection{Pengukuran Produktivitas Bakteri}

Pembuatan larutan urea $10 \%$ dibuat dengan cara $10 \mathrm{~g}$ urea ditimbang lalu dimasukkan ke dalam $100 \mathrm{ml}$ akuades. Sementara itu, larutan Na-hipoklorit dibuat dengan cara diambil 281,7 $\mathrm{ml} \mathrm{NaOCl}$ lalu dituangkan ke dalam 1.000 ml akuades.

Larutan buffer sitrat dibuat dengan cara seperti berikut: sebanyak $300 \mathrm{~g}$ kalium sitrat ditimbang lalu dilarutkan ke dalam $700 \mathrm{ml}$ akuades. Setelah itu ditera hingga mencapai volume $1.000 \mathrm{ml}$ dan diukur $\mathrm{pH}$ hingga mencapai 6,7 .

Larutan Natrium-fenol dibuat dengan cara seperti berikut: tahap pertama sebanyak $6,25 \mathrm{~g}$ fenol ditimbang dan dimasukkan ke dalam $20 \mathrm{ml}$ etanol, lalu ditambahkan $2 \mathrm{ml}$ metanol dan 18,5 $\mathrm{ml}$ aseton kemudian ditambahkan etanol hingga volume $100 \mathrm{ml}$ dan dikocok hingga homogen (a). Tahap kedua, sebanyak $27 \mathrm{~g} \mathrm{NaOH}$ dilarutkan dalam $100 \mathrm{ml}$ akuades (b). Tahap ketiga, larutan (a) dan (b) diambil masing-masing sebanyak 20 $\mathrm{ml}$ lalu ditambahkan dengan akuades hingga volume $100 \mathrm{ml}$.

Larutan stok amonium sulfat dibuat dengan

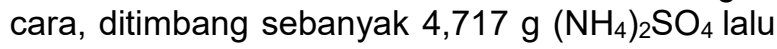
dimasukkan ke dalam $1.000 \mathrm{ml}$ akuades. Larutan standar amonium sulfat dibuat dengan cara $10 \mathrm{ml}$ larutan stok dituangkan ke dalam $990 \mathrm{ml}$ akuades. Cara kerja yang dilakukan ialah disiapkan labu ukur $50 \mathrm{ml}$, lalu dipipet larutan untuk kurva standar sebanyak masing-masing 0 , 1, 2, 3, 4, 6, 8, 10, 12, 14, 16, 18, $20 \mathrm{ml}$. Jumlah pipet tersebut setara dengan $0 ; 0,2 ; 0,4 ; 0,6 ; 0,8$; 1,$2 ; 1,6 ; 2$, dan 2,$4 ; 2,6 ; 2,8 ; 4$ ppm NH $\mathrm{N}_{3}-\mathrm{N} / \mathrm{ml}$. Setelah itu secara berturut-turut ditambahkan 10 $\mathrm{ml}$ akuades, $4 \mathrm{ml}$ natrium fenol dan $3 \mathrm{ml}$ larutan $\mathrm{NaOCl}$ lalu dikocok hingga homogen selama 20 menit. Setelah 20 menit, volume dibuat menjadi $50 \mathrm{ml}$ dan diukur intensitas cahayanya pada panjang gelombang $590 \mathrm{~nm}$ pada spektrofotometer Jasco V 530.

Larutan blanko dibuat sebagai kontrol suatu senyawa yang akan diuji. Larutan blanko dibuat dengan cara melarutkan $4 \mathrm{ml}$ natrium fenol dan 3 $\mathrm{ml}$ larutan $\mathrm{NaOCl}$ dengan menambahkan $10 \mathrm{ml}$ akuades lalu ditera hingga volume $50 \mathrm{ml}$ dan dihomogenkan. 
Persiapan isolat dilakukan dengan cara, diambil 1 ose dari stok kultur lalu diinokulasikan ke dalam $10 \mathrm{ml}$ tabung berisi urea base cair setelah itu diinkubasi selama 7 hari pada suhu $35^{\circ}$ C. Setelah itu, diambil $1 \mathrm{ml}$ inokulum lalu dimasukkan ke dalam 8 tabung reaksi berisikan 9 $\mathrm{ml}$ urea base cair. 4 tabung untuk pengukuran $\mathrm{H} 0$ dan 4 tabung lainnya untuk pengukuran $\mathrm{H} 7$. Pengukuran yang dilakukan antara lain $\mathrm{pH}$, suhu, Optical Density (OD), Total Plate Count (TPC) dan kadar amonia. Cara ini dilakukan untuk 3 kali ulangan.

Konsentrasi amonia merupakan produk dari aktivitas urease. Pengukuran konsentrasi amonia dilakukan dalam medium urea base. Sebanyak 9 $\mathrm{ml}$ medium dan $1 \mathrm{ml}$ kultur bakteri berumur 7 hari dimasukkan ke dalam labu ukur $100 \mathrm{ml}$ lalu ditambahkan $15 \mathrm{ml}$ toluena setelah itu dikocok hingga homogen. Setelah 15 menit ditambahkan $10 \mathrm{ml}$ larutan urea $10 \%$ dan $20 \mathrm{ml}$ larutan buffer sitrat pH 6,7 dan dikocok hingga homogen. Kemudian labu ukur ditutup dengan sumbat dan inokulum siap diinkubasi pada suhu $37^{\circ} \mathrm{C}$ selama 3 jam. Selanjutnya, setelah 3 jam ditambahkan akuades ke dalam labu ukur hingga volume menjadi $100 \mathrm{ml}$, kemudian tutup dan dikocok hingga homogen. Suspensi disaring dengan menggunakan kertas saring. Lalu, sebanyak $1 \mathrm{ml}$ filtrat, $10 \mathrm{ml}$ akuades, $4 \mathrm{ml}$ larutan Na-fenol dan 3 ml larutan $\mathrm{NaOCl}$ dimasukkan ke dalam labu ukur $50 \mathrm{ml}$ kemudian dikocok hingga homogen lalu didiamkan selama 20 menit. Selanjutnya ditambahkan akuades hingga volume $50 \mathrm{ml}$ dan dikocok kembali hingga homogen.

Pengukuran kadar amonia diukur menggunakan spektrofotometer Jasco V 530 dengan panjang gelombang $590 \mathrm{~nm}$. Konsentrasi amonia sampel $(\mathrm{x})$ dapat dihitung dengan meregresikan nilai absorbansi (y) dan konstanta $(a, b)$ dari persamaan $y=a x+b$.

Konsentrasi sel bakteri diperiksa dengan mengamati Optical Density (OD). Nilai Optical Density diketahui dari Total Plate Count (TPC) yang digunakan untuk membuat kurva standar.
Konsentrasi sel dibuat dengan cara mengambil 1 $\mathrm{ml}$ stok kultur bakteri lalu dituangkan ke dalam 9 $\mathrm{ml}$ medium urea base steril (pengenceran $10^{-2}$ ), lalu dilanjutkan hingga pengenceran $10^{-5}$ dan dikocok hingga homogen. Kemudian diambil 0,1 $\mathrm{ml}$ dari 2 pengenceran terakhir $\left(10^{-4}\right.$ dan $\left.10^{-5}\right)$ lalu diinokulasikan ke dalam medium urea agar base dan diratakan menggunakan batang L. Setelah itu, diinkubasi pada suhu $35^{\circ} \mathrm{C}$ selama $1 \times 24$ jam dan dihitung koloni yang muncul pada media. Sembilan mililiter media dan $1 \mathrm{ml}$ inokulum diukur $\mathrm{pH}$ dan suhu pada masing-masing isolat. Pengukuran $\mathrm{pH}$ diukur menggunakan $\mathrm{pH}$ meter. Sementara itu, diukur pula-suhu menggunakan termometer Celcius hingga menandakan suhu yang tepat. Pengukuran dilakukan dengan cara yang sama pada hari ke-0 dan ke-7.

\subsection{Analisis Data}

Data pengukuran konsentrasi amonia, konsentrasi sel bakteri, $\mathrm{pH}$, dan suhu ditampilkan dari selisih pengukuran hari ke-0 dan ke-7 serta dianalisis menggunakan analisis variansi dengan taraf nyata $5 \%$ untuk mengetahui perbedaan antar isolat.

\section{HASIL DAN PEMBAHASAN}

\subsection{Hasil Isolasi Bakteri}

Hasil isolasi bakteri dari sampel sedimen mangrove asal Muara Gembong adalah 6 macam bakteri berdasarkan perbedaan karakteristik morfologi dan koloni sel. Karakteristik yang teramati pada masing-masing isolat dapat dilihat pada Tabel 1. Hasil pengamatan morfologi koloni yang diperoleh antara lain, irregular dan rhizoid, memiliki permukaan rata (flat) serta warna putih kekuningan dan putih kecoklatan. Gambar koloni bakteri dapat dilihat pada Gambar 2. Hasil pewarnaan Gram menunjukkan 6 isolat yang diperoleh termasuk ke dalam Gram positif dan bentuk bacil (Gambar 2).

Tabel 1. Karakteristik Isolat Bakteri

\begin{tabular}{ccccccc}
\hline \multirow{2}{*}{$\begin{array}{c}\text { Kode } \\
\text { Isolat }\end{array}$} & \multicolumn{3}{c}{ Karakteristik Koloni } & \multicolumn{2}{c}{ Karakteristik Sel } \\
\cline { 2 - 7 } & Bentuk & Tepi & Permukaan & Warna & Gram & Bentuk \\
\hline K1 & Irregular & Rhizoid & Flat & Putih kekuningan & Positif & Bacil \\
\hline K7 & Rhizoid & Rhizoid & Flat & Putih kekuningan & Positif & Bacil \\
\hline K9 & Irregular & Lobate & Flat & Putih kekuningan & Positif & Bacil \\
\hline K5A & Irregular & Undulate & Flat & Putih kecoklatan & Positif & Bacil \\
\hline K5B & Irregular & Curled & Flat & Putih kekuningan & Positif & Bacil \\
\hline K6A & Rhizoid & Lobate & Flat & Putih kekuningan & Positif & Bacil \\
\hline Keterangan: & & & & & &
\end{tabular}




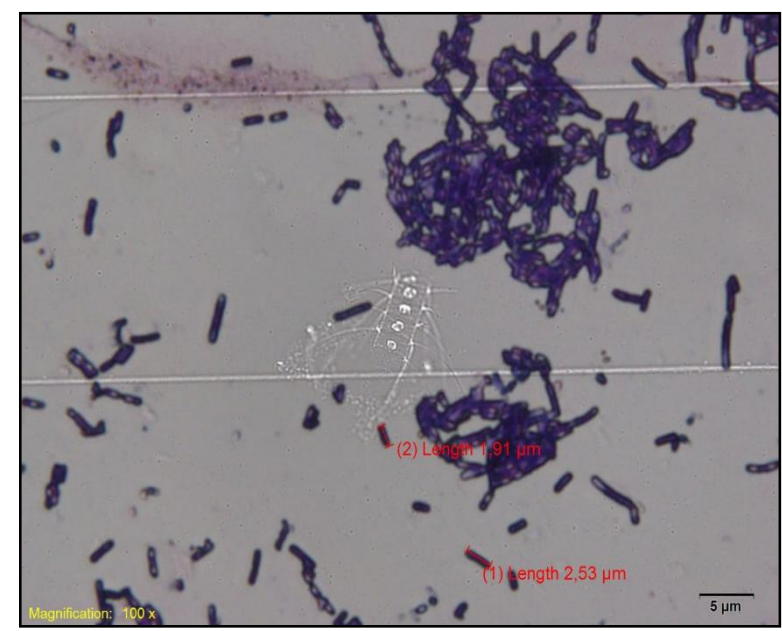

Gambar 2. Morfologi Sel Bakteri Ureolitik (Isolat K7, Perbesaran 1.000x)

\subsection{Produktivitas Isolat Bakteri}

Produktivitas isolat bakteri ureolitik dapat ditunjukkan dari hasil kenaikan konsentrasi produksi ammonia dan konsentrasi sel bakteri yang didukung dengan faktor $\mathrm{pH}$ dan suhu per satuan volume $10 \mathrm{ml}$. Produksi konsentrasi amonia tertinggi terjadi pada isolat bakteri $\mathrm{K} 5 \mathrm{~A}$ sebesar 15,19 ppm dan tertinggi kedua diperoleh pada isolat bakteri K7 sebesar 14,10 ppm (Tabel 2 dan Gambar 3). Kenaikan konsentrasi amonia dari keenam isolat menunjukkan perbedaan yang nyata berdasarkan analisis variansi (Tabel 3).

Produktivitas selanjutnya dapat dilihat dari kenaikan konsentrasi sel bakteri. Berdasarkan analisis variansi, masing-masing isolat berpengaruh nyata terhadap kenaikan konsentrasi sel bakteri. Kenaikan konsentrasi sel

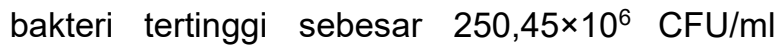
terjadi pada isolat bakteri $\mathrm{K} 5 \mathrm{~A}$, sedangkan isolat bakteri $\mathrm{K} 7$ memperoleh kenaikan konsentrasi sel

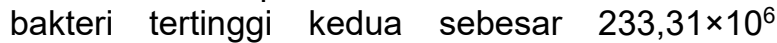
CFU/ml (Tabel 2 dan Gambar 4).

Produktivitas bakteri didukung juga oleh faktor $\mathrm{pH}$. Kenaikan $\mathrm{pH}$ memiliki perbedaan yang nyata antar keenam isolat bakteri berdasarkan analisis variansi (Tabel 3 ). Isolat bakteri $\mathrm{K} 5 \mathrm{~A}$ memiliki kenaikan $\mathrm{pH}$ tertinggi sebesar 3,27 dan kenaikan $\mathrm{pH}$ tertinggi berikutnya adalah isolat bakteri K7 sebesar 2,89 (Tabel 2). Sementara itu, nilai rata-rata $\mathrm{pH}$ awal $(\mathrm{H} 0)$ sebesar 6,14 (asam) sedangkan rata-rata $\mathrm{pH}$ akhir $(\mathrm{H} 7)$ sebesar 8,36 (basa) (Gambar 5)

Tabel 2. Data Produktivitas Isolat Bakteri

\begin{tabular}{ccccc}
\hline \multirow{2}{*}{ Jenis Isolat } & \multicolumn{4}{c}{ Data Rata-rata Tiap Parameter } \\
\cline { 2 - 5 } & $\begin{array}{c}\text { Konsentrasi Amonia } \\
(\mathrm{ppm})\end{array}$ & $\begin{array}{c}\text { Konsentrasi Sel } \\
\left(\times 10^{6} \mathrm{CFU} / \mathrm{ml}\right)\end{array}$ & Kenaikan pH & Kenaikan Suhu $\left({ }^{\circ} \mathrm{C}\right)$ \\
\hline $\mathrm{K} 1$ & 1,41 & 26,3 & 1,32 & 3,83 \\
\hline $\mathrm{K} 7$ & 14,1 & 233,31 & 2,89 & 2,5 \\
\hline $\mathrm{K} 9$ & 9,78 & 152,79 & 2,2 & 1,33 \\
\hline $\mathrm{K} 5 \mathrm{~A}$ & 15,19 & 250,45 & 3,27 & 2,83 \\
\hline $\mathrm{K} 5 \mathrm{~B}$ & 5,54 & 49,6 & 1,65 & 2,67 \\
\hline $\mathrm{K} 6 \mathrm{~A}$ & 5,87 & 51,23 & 1,96 & 2,67 \\
\hline
\end{tabular}

Tabel 3. Hasil Analisis Variansi

\begin{tabular}{|c|c|c|c|c|c|c|}
\hline & & Sum of Squares & df & Mean Square & $\mathrm{F}$ & Significant \\
\hline \multirow{3}{*}{ Amonia } & Between Groups & 430,937 & 5 & 86,187 & 7,778 & 0,002 \\
\hline & Within Groups & 132,967 & 12 & 11,081 & & \\
\hline & Total & 563,903 & 17 & & & \\
\hline \multirow{3}{*}{ TPC } & Between Groups & 141337078077777776,000 & 5 & 28267415615555556,000 & 12,173 & 0,000 \\
\hline & Within Groups & 27864793083333336,000 & 12 & 2322066090277778,000 & & \\
\hline & Total & 169201871161111104,000 & 17 & & & \\
\hline \multirow{3}{*}{$\mathrm{pH}$} & Between Groups & 8,255 & 5 & 1,651 & 4,056 & 0,022 \\
\hline & Within Groups & 4,884 & 12 & ,407 & & \\
\hline & Total & 13,139 & 17 & & & \\
\hline \multirow{3}{*}{ Suhu } & Between Groups & 9,569 & 5 & 1,914 & 6,890 & 0,003 \\
\hline & Within Groups & 3,333 & 12 & ,278 & & \\
\hline & Total & 12,903 & 17 & & & \\
\hline
\end{tabular}




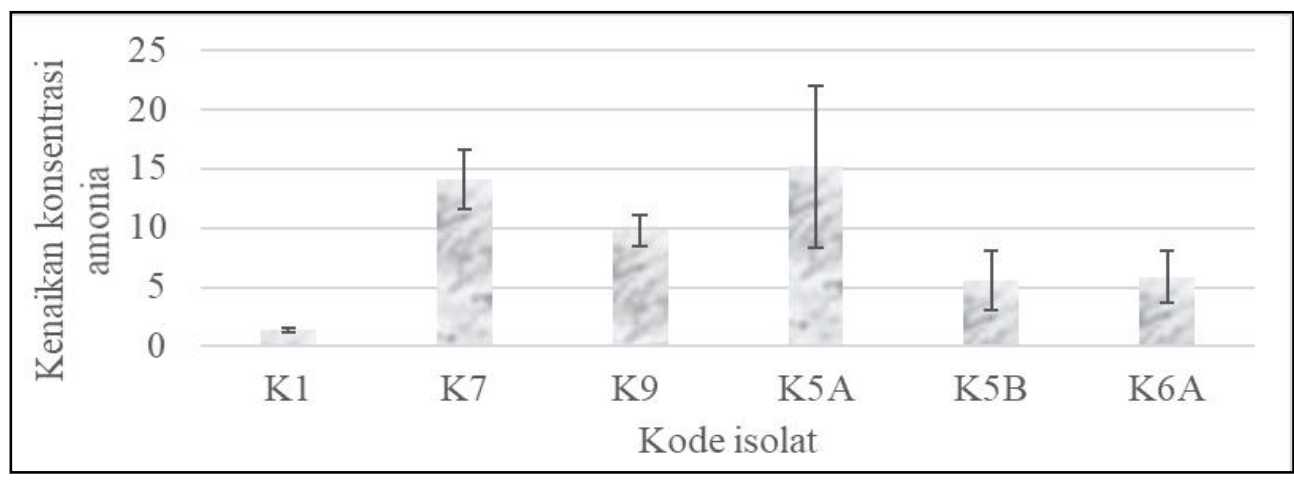

Gambar 3. Rata-rata kenaikan konsentrasi ammonia (dalam satuan ppm per volume $10 \mathrm{ml}$ )

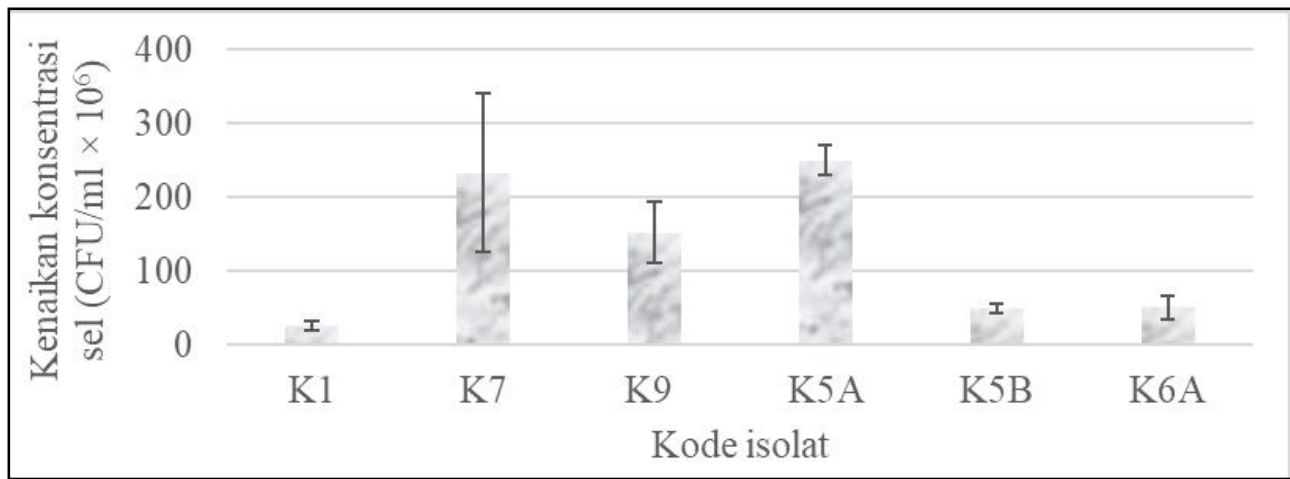

Gambar 4. Rata-rata kenaikan konsentrasi sel bakteri (dalam satuan $\times 10^{6} \mathrm{CFU} / \mathrm{ml}$ )

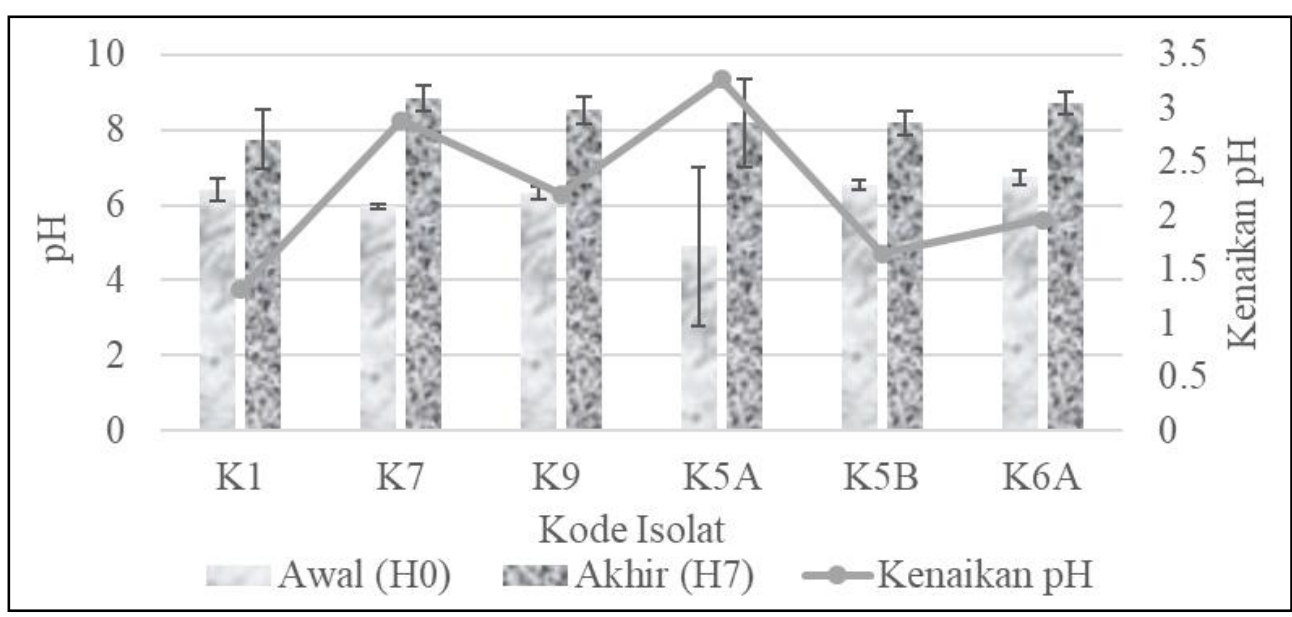

Gambar 5 Rata-rata $\mathrm{pH}$ dan nilai kenaikan $\mathrm{pH}$

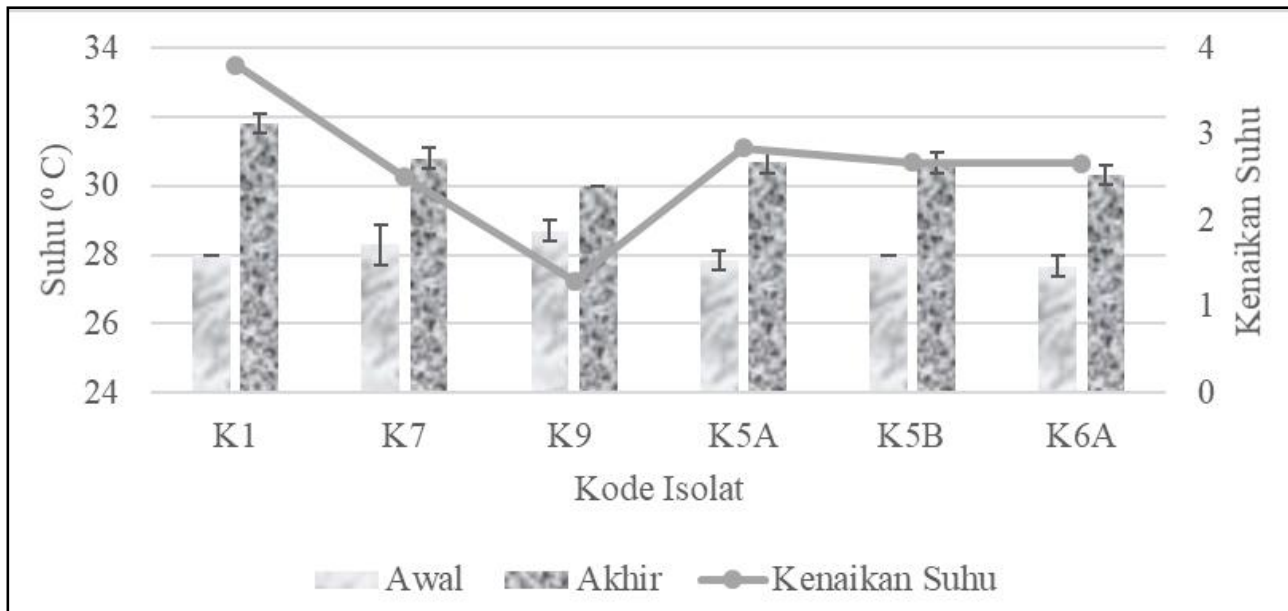

Gambar 6. Rata-rata suhu dan nilai kenaikan suhu 
Faktor pendukung produktivitas isolat bakteri yang lain, yaitu suhu (Gambar 6). Kenaikan suhu dari keenam isolat menunjukkan perbedaan yang nyata berdasarkan analisis variansi (Tabel 3). Kenaikan suhu tertinggi terjadi pada isolat bakteri $\mathrm{K} 1$ sebesar $3,83{ }^{\circ} \mathrm{C}$ dan kenaikan suhu tertinggi kedua sebesar $2,83^{\circ} \mathrm{C}$ dimiliki oleh isolat bakteri K5A (Tabel 2). Sementara itu, nilai rata-rata suhu awal dan suhu akhir secara berurutan, yaitu $28,08^{\circ} \mathrm{C}$ dan $30,71^{\circ} \mathrm{C}$ (Gambar 6).

\subsection{Pembahasan}

Penelitian ini menemukan 6 isolat positif bakteri ureolitik dengan karakteristik berbentuk bacil (batang) dan Gram-positif. Sedangkan pada penelitian lain telah ditemukan juga bakteri ureolitik dari sedimen mangrove di kota Bontang, hasil yang ditemukan adalah 5 isolat bakteri positif jenis ureolitik yang terdiri dari 2 isolat memiliki karakteristik Gram-positif dan 4 isolat adalah Gram-negatif( ${ }^{(7)}$. Karena kawasan mangrove merupakan tempat pertemuan antara muara daratan dan lautan serta dipengaruhi oleh pasang surut air laut ${ }^{(8)}$. Dengan demikian sedimen mangrove mampu mendukung pertumbuhan bakteri untuk proses isolasi bakteri ureolitik maupun mikroorganisme laut lain.

Produktivitas keenam isolat bakteri yang ditemukan pada penelitian ini memiliki kenaikan konsentrasi amonia yang berbeda-beda. Kenaikan konsentrasi amonia tertinggi dimiliki oleh isolat bakteri K5A. Nilai konsentrasi ammonia isolat bakteri K5A yaitu sebesar 15,19 ppm lebih rendah dibandingkann dengan penelitian lain sebesar $22,75 \mathrm{ppm}^{(9)}$. Hal ini disebabkan mungkin karena perubahan kondisi medium dari urea agar base ke medium urea base sehingga isolat bakterinya membutuhkan waktu beradaptasi yang lebih lama dalam mendegradasi urea. Menurut Disi et al., sejumlah isolat bakteri ureolitik dengan produksi urease yang lebih rendah memerlukan lebih banyak waktu untuk menghidrolisis urea dibandingkan dengan isolat bakteri ureolitik dengan produksi urease yang lebih tinggi karena perubahan kondisinya ${ }^{(10)}$.

Kenaikan konsentrasi amonia yang dihasilkan adalah karena adanya peran bakteri. Konsentrasi bakteri selain berperan sebagai katalis dalam menghidrolisis urea juga memainkan peran penting karena sel-sel bakteri berfungsi sebagai situs nukleasi untuk pengendapan $\mathrm{CaCO}_{3}{ }^{(11)}$. Kenaikan konsentrasi sel bakteri tertinggi dimiliki oleh isolat bakteri K5A yaitu sebesar $250,45 \times 10^{6} \mathrm{CFU} / \mathrm{ml}$. Nilai ini lebih tinggi daripada nilai kenaikan konsentrasi sel bakteri pada penelitian lain, yaitu $57 \times 10^{6}$ $\mathrm{CFU} / \mathrm{ml}^{(9)}$. Hal ini dikarenakan urea yang ditambahkan lebih besar $20 \%$ dibandingkan konsentrasi urea pada penelitian lain. Urea yang ditambahkan digunakan oleh bakteri ureolitik sebagai sumber nitrogen. Bakteri membutuhkan sumber nitrogen untuk mendukung pertumbuhan maksimalnya karena nitrogen merupakan kunci pembentuk protein, enzim dan asam nukleat ${ }^{(12)}$.

Kenaikan konsentrasi amonia pada isolat bakteri K5A dan K7 memperlihatkan bahwa kenaikan konsentrasi amonia dan konsentrasi sel bakteri berbanding lurus. Hal ini menandakan kenaikan konsentrasi amonia dipengaruhi oleh tingginya konsentrasi sel bakteri. Berlangsungnya proses hidrolisis urea tergantung dari ada tidaknya bakteri yang dapat menghasilkan enzim-enzim urease ${ }^{(13)}$. Ketika urea dihidrolisis oleh bakteri maka diketahui terdapat enzim urease yang dimiliki pada bakteri tersebut sehingga menghasilkan amonia dan asam karbonat yang kemudian akan terurai menjadi amonia dan karbon dioksida yang akan meningkatkan $\mathrm{pH}$ dan mempercepat laju pengendapan kalsium karbonat ${ }^{(14)}$ (Gambar 7 dan Gambar 8).

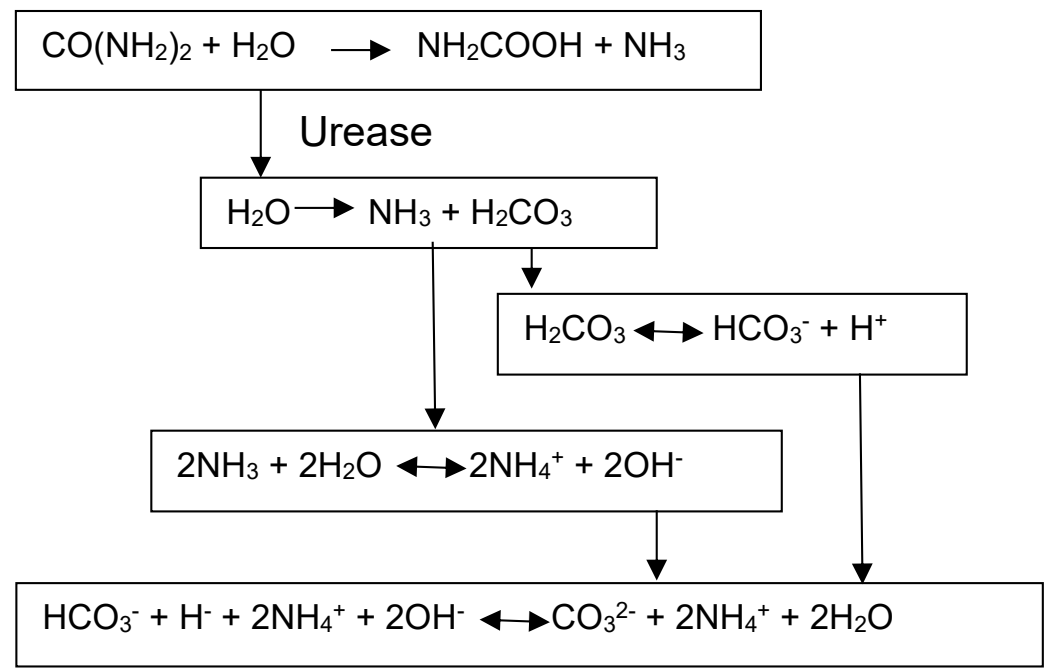

Gambar 7. Reaksi tahapan hidrolisis urea yang dikatalis oleh enzim urease, Sumber : Goenadi(14) 


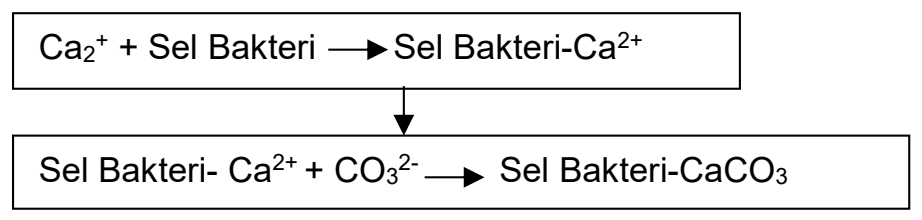

Gambar 8. Mekanisme pengendapan $\mathrm{CaCO}_{3}$ oleh sel bakteri, Sumber : Goenadi(14)

Berdasarkan penelitian ini konsentrasi amonia yang dihasilkan sebanding dengan nilai konsentrasi sel bakteri dan tingginya nilai $\mathrm{pH}$. Isolat bakteri K5A memproduksi konsentrasi amonia sebesar 15,19 ppm sebanding dengan tingginya nilai konsentrasi sel bakteri sebesar $250,45 \times 10^{6} \mathrm{CFU} / \mathrm{ml}$ dan diikuti oleh kenaikan $\mathrm{pH}$ sebesar 3,27 yang juga paling besar kenaikannya di antara isolat lainnya. Tingkat hidrolisis urea berbanding lurus dengan konsentrasi bakteri, $\mathrm{pH}$, dan suhu. Bakteri dengan konsentrasi tinggi menghasilkan lebih banyak urease per unit volume untuk memulai hidrolisis urea ${ }^{(15)}$. Karena telah terjadi hidrolisis urea yang dikatalis oleh enzim urease pada bakteri ureolitik maka akan dihasilkan produk berupa amonia. Adanya amonia dapat mendorong kenaikan $\mathrm{pH}$ pada medium bakteri tumbuh. Nilai $\mathrm{pH}$ lingkungan dapat mempengaruhi keefektifan sisi aktif enzim dalam membentuk kompleks enzim dengan substrat ${ }^{(16)}$. Dengan demikian kenaikan konsentrasi sel isolat bakteri berperan untuk mempercepat proses terjadinya degradasi urea karena adanya enzim urease pada isolat bakteri tersebut yang menjadi pemeran utama dalam proses biogrouting.

Dari berbagai studi pustaka diketahui bahwa salah satu faktor pendukung dari produktivitas bakteri adalah $\mathrm{pH}$. Dalam penelitian ini diketahui bahwa nilai $\mathrm{pH}$ awal menunjukkan $\mathrm{pH}$ asam sedangkan setelah 7 hari inkubasi nilai $\mathrm{pH}$ menjadi basa. Penelitian lain menunjukkan nilai $\mathrm{pH}$ awal sebesar 6,9 dan $\mathrm{pH}$ akhir sebesar 9 dalam kurun waktu 7 hari(17). Perubahan $\mathrm{pH}$ yang terjadi menandakan telah terjadi degradasi urea menjadi produk amonia oleh isolat bakteri. Proses hidrolisis urea yang terjadi menyebabkan $\mathrm{pH}$ medium menjadi basa. Kenaikan $\mathrm{pH}$ menjadi basa dikarenakan gugus hidroksil $\left(\mathrm{OH}^{-}\right)$yang terbentuk dari produksi $\mathrm{NH}_{4}{ }^{+}$akan menggeser kesetimbangan bikarbonat dan membentuk ion karbonat $\left(\mathrm{CaCO}_{3}{ }^{2-}\right)$ sehingga terbentuk lingkungan yang basa ${ }^{(18)}$.

Kenaikan $\mathrm{pH}$ tertinggi pada penelitian ini ditunjukkan oleh isolat bakteri K5A. Nilai kenaikan $\mathrm{pH}$ pada isolat bakteri $\mathrm{K} 5 \mathrm{~A}$ sebesar 3,27 yang berarti nilai ini lebih besar daripada kenaikan $\mathrm{pH}$ pada penelitian lain, yaitu sebesar $2^{(16)}$. Kenaikan $\mathrm{pH}$ yang berbeda dapat disebabkan oleh sumber isolat dan strain bakteri yang berbeda. Oleh karena itu, dari perbedaan ini juga dapat dihasilkan karakteristik enzim urease yang berbeda atau asam amino penyusun enzim yang berbeda sehingga pengaruh terhadap $\mathrm{pH}$ juga akan memberikan perbedaan pada aktivitas enzimnya. Karakteristik enzim yang berbeda dapat berasal dari perubahan tingkat ionisasi dalam enzim atau substrat yang berbeda sehingga akan mempengaruhi aktivitas dan ketika terjadi kenaikan $\mathrm{pH}$ konformasi enzim berada dalam kondisi ideal yang menyebabkan interaksi antara enzim dan substrat menjadi maksimal dalam proses degradasi urea yang membentuk produk (amonia) $^{(16)}$. Kenaikan $\mathrm{pH}$ mengontrol kelangsungan hidup dan aktivitas metabolisme mikroorganisme yang secara tidak langsung mempengaruhi sekresi produk ${ }^{(19)}$. Dengan demikian $\mathrm{pH}$ dapat mempengaruhi produk akhir dari hidrolisis urea, yaitu konsentrasi amonia.

Berdasarkan hasil yang diperoleh, kenaikan konsentrasi amonia berbanding lurus dengan kenaikan $\mathrm{pH}$. Kenaikan konsentrasi amonia pada isolat bakteri K5A lebih tinggi dibandingkan pada isolat bakteri K7. Nilai ini sebanding dengan nilai kenaikan $\mathrm{pH}$ pada isolat bakteri K5A yang lebih tinggi daripada isolat bakteri K7. Pada penelitian lain menunjukkan ketika $\mathrm{pH} 5$ aktivitas urease yang dihasilkan hanya $70 \%$, namun ketika $\mathrm{pH} 7$ aktivitas urease meningkat menjadi 100\%; dengan demkian kenaikan $\mathrm{pH}$ sebesar 2 dapat menaikkan konsentrasi amonia hingga $30 \%{ }^{(16)}$. Dengan kata lain, kenaikan $\mathrm{pH}$ yang tinggi menghasilkan tingginya kenaikan konsentrasi amonia, sedangkan saat kenaikan $\mathrm{pH}$ lebih rendah menyebabkan konsentrasi amonia yang dihasilkan tidak maksimal. Hal ini mungkin terjadi karena struktur tiga dimensi enzim mulai berubah, sehingga substrat tidak dapat berikatan dengan sisi aktif enzim akibatnya proses katalis tidak dapat berlangsung secara sempurna(20). Dengan demikian kenaikan $\mathrm{pH}$ menjadi penting karena dapat mempengaruhi kerja enzim urease yang dimiliki oleh bakteri ureolitik.

Nilai suhu awal lebih rendah daripada suhu akhir. Suhu yang lebih rendah mengikuti rendahnya kenaikan konsentrasi amonia hari ke0 dibandingkan dengan hari ke-7. Hasil yang didapatkan sesuai dengan hasil pada penelitian lain yaitu bahwa suhu $25^{\circ} \mathrm{C}$ hanya menghasilkan konsentrasi amonia $36 \%$, sedangkan dengan suhu $35^{\circ} \mathrm{C}$ aktivitas urease menjadi optimum ${ }^{(16)}$. Hal ini diperkirakan karena adanya peran bakteri yang mempengaruhi suhu pada medium menjadi meningkat dalam waktu 7 hari. Hasil penelitian lain sebelumnya menunjukkan bahwa 
keberadaan isolat bakteri dalam menghasilkan enzim urease dapat mengubah substrat urea menjadi lebih mudah menguap ${ }^{(21)}$.

Kenaikan suhu dapat menghasilkan produktivitas yang berbeda-beda pada masingmasing isolat bakteri. Rata-rata kenaikan suhu pada penelitian ini sebesar $2,63{ }^{\circ} \mathrm{C}$. Hasil penelitian lain menunjukkan bahwa kenaikan suhu sebesar $10{ }^{\circ} \mathrm{C}$ dapat meningkatkan 10 kali lebih besar pada aktivitas urease ${ }^{(11)}$. Kenaikan aktivitas enzim disebabkan oleh meningkatnya energi kinetik molekul-molekul yang bereaksi (meningkatnya frekuensi tumbukan) karena pengaruh kenaikan suhu ${ }^{(22)}$. Bertambahnya energi kinetik akan mempercepat gerak vibrasi, translasi dan rotasi baik enzim maupun substrat, hal ini akan memperbesar peluang enzim dan substrat bereaksi(23).

Pada penelitian ini diketahui bahwa kenaikan suhu paling tinggi terjadi pada isolat bakteri K1 (Gambar 6), hal ini tidak sebanding dengan rendahnya kenaikan konsentrasi amonia dan kenaikan konsentrasi sel bakterinya. Ini menunjukkan bahwa pertumbuhan bakteri dapat dihambat karena peran kenaikan suhu lebih besar daripada pengaruh enzim urease yang terekspresikan oleh bakteri(24). Kenaikan suhu yang terlalu tinggi akan menyebabkan enzim mengalami denaturasi dan kehilangan aktivitas katalitiknya (inaktivasi). Proses inaktivasi enzim pada suhu tinggi diawali dengan pembukaan struktur molekul enzim akibat putusnya ikatan hidrogen, sehingga terjadi perubahan konformasi pada struktur asam aminonya baik pada sisi aktif maupun pada protein pendukung pada enzim, akibatnya enzim menjadi inaktif atau mengalami penurunan aktivitas enzim(23). Sementara itu, kenaikan suhu pada isolat bakteri $\mathrm{K} 5 \mathrm{~A}$ memiliki nilai yang sebanding dengan konsentrasi amonia dan konsentrasi sel yang tinggi. Hal ini diperkirakan karena telah dihasilkannya produk (amonia) dan $\mathrm{CO}_{2}$ yang berasal dari hidrolisis urea oleh enzim urease yang menyebabkan suhu pada medium menjadi meningkat. Terjadinya kenaikan suhu pada medium disebabkan karena bertambahnya energi kinetik yang mendorong tumbukan antara enzim dan substratnya, dan mampu merangsang modifikasi pada membran sel bakteri yang mempengaruhi sekresi produk menjadi lebih cepat ${ }^{(25)}$. Dengan besarnya peluang antara enzim urease dan substrat untuk bereaksi maka akan memperbesar produk akhir yang dihasilkan (amonia) oleh bakteri ureolitik tersebut.

\section{KESIMPULAN DAN SARAN}

Dari hasil dan pembahasan di atas dapat ditarik kesimpulan bahwa enam isolat bakteri ureolitik berhasil diisolasi dari sampel sedimen mangrove asal Muara Gembong, Bekasi.
Produktivitas ureoltik isolat bakteri $\mathrm{K} 5 \mathrm{~A}$ dan $\mathrm{K} 7$ tergolong rendah, yaitu berturut-turut sebesar 15,19 ppm dan 14,10 ppm ammonia yang diproduksi per satuan volume $10 \mathrm{ml}$ media jika dibandingkan dengan produktivitas urease yang dihasilkan pada penelitian lain sebelumnya. Kenaikan konsentrasi amonia berbanding lurus dengan kenaikan konsentrasi sel bakteri, $\mathrm{pH}$ dan suhu. Untuk penelitian berikutnya disarankan agar isolat bakteri $\mathrm{K} 5 \mathrm{~A}$ dan $\mathrm{K} 7$ ini dapat dilakukan uji optimasi di dalam bioreaktor dengan pengaturan faktor-faktor yang berpengaruh nyata terhadap produktivitas urease yang dihasilkannya sehingga nantinya dapat dijadikan kandidat isolat unggul untuk proses biosementasi. Identifikasi secara molekuler juga perlu dilakukan pada penelitian berikutnya agar dapat diketahui species kedua isolat tersebut secara pasti sebelum dimanfaatkan dalam aplikasi/penerapan yang lebih luas lagi.

\section{PERSANTUNAN}

Para penulis menyampaikan terima kasih kepada Kementerian Riset Teknologi dan Pendidikan Tinggi Program Insentif Riset Nasional (Insinas) tahun 2019 atas bantuan pendanaan dan kepada Pusat Teknologi Lingkungan (PTL)-TPSA-BPPT beserta semua staf yang terlibat dalam kegiatan Insinas 2019 RISTEKDIKTI ini. Kontributor utama untuk Karya Tulis IImiah ini adalah Aflakhur Ridlo dan Hanies Ambarsari, sedangkan penulis lainnya adalah sebagai kontributor anggota.

\section{DAFTAR PUSTAKA}

1. Ivanov, V. \& Chu, J. (2008) Applications of microorganisms to geotechnical engineering for bioclogging and biocementation of soil in situ. Environ Sci. Biotechnolo. 7:139-153.

2. Ardiyanti, D. (2019). isolasi dan produktivitas bakteri ureolitik dari sampel sedimen sungai asal muara gembong Bekasi.

3. De Muynck, W., De Belie, N., \& Verstraete, W. (2010). Microbial carbonate precipitation in construction materials: A review. Ecological Engineering, 36(2), 118-136. https://doi.org/10.1016/j.ecoleng.2009.02.006

4. Lee, O. P. (2017). Examination of relationships between bacterial communities, urease activity, and environmental variables over space and time in gulf of mexico wetlands. https://doi.org/10.1360/zd-2013-436-1064

5. Kehutanan, K. L. H. K. (2015). Album peta kepekaan lingkungan wilayah pesisir dan laut teluk jakarta. 
6. Cappuccino., J. G., \& Sherman, N. (2014). Microbiology: A Laboratory Manual. Clinical application.

7. Dewi, A. K., Meylina, L., \& Rusli, R. (2017). Isolasi bakteri dari tanah mangrove Rhizopora sp. di kota bontang. In Proceeding of the 5th Mulawarman Pharmaceuticals Conferences (Vol. 53, p. 500). https://doi.org/10.1093/icon/moq014

8. Ambinari, M. (2016). Penataan peran para pihak dalam pengelolaan hutan mangrove di Teluk Jakarta. Thesis.

9. Bibi, S., Oualha, M., Ashfaq, M. Y., Suleiman, M. T., \& Zouari, N. (2018). Isolation, differentiation and biodiversity of ureolytic bacteria of Qatari soil and their potential in microbially induced calcite precipitation (MICP) for soil stabilization. RSC Advances, 8(11), 5854-5863.

https://doi.org/10.1039/c7ra12758h

10.Disi, Z. Al, Jaoua, S., Al-thani, D., Al-meer, S., \& Zouari, N. (2017). Considering the specific impact of harsh conditions and oil weathering on diversity, adaptation, and activity of hydrocarbon-degrading bacteria in strategies of bioremediation of harsh Oily-polluted soils. Biomed Research International, (January), 11.

11.Imran, M. Al, Shinmura, M., Nakashima, K., \& Satoru, K. (2018). Effects of various factors on carbonate particle growth using ureolytic bacteria. Materials Transactions, 70612(116), 1-5. https://doi.org/10.1271/bbb.70612

12. Hamzah, A., Phan, C. W., Abu Bakar, N. F., \& Wong, K. K. (2013). Biodegradation of crude oil by constructed bacterial consortia and the constituent single bacteria isolated from Malaysia. Bioremediation Journal, 17(1), 1-10. https://doi.org/10.1080/10889868.2012.73144 7

13. Darpita, S. D. K., Starinda, E. A., \& Ardhiani, C. (2011). Profil hidrolisis urea pada berbagai jenis tanah. Saintifika, III(1).

14. Goenadi, D. H. (2017). Perbaikan sifat fisikamekanis tanah dengan mediasi teknik hayati. Menara Perkebunan, 85(1), 44-52.

15.Jawad Kadhim, F., \& Zheng, J.-J. (2016). Review of the factors that influence on the microbial induced calcite precipitation. Civil and Environmental Research, 8(10), 69-76. Retrieved from http://www.iiste.org/Journals/index.php/CER/a rticle/viewFile/33340/34280.
16.Zusfahair, Ningsih, D. R., Fatoni, A., \& Pertiwi, D. S. (2018). Determination of urease biochemical properties of asparagus bean (Vigna unguiculata ssp sesquipedalis L.). IOP Conference Series: Materials Science and Engineering, https://doi.org/10.1088/1757899X/349/1/012073.

17.Arias, D., Cisternas, L. A., Miranda, C., \& Rivas, M. (2019). Bioprospecting of ureolytic bacteria from laguna salada for biomineralization applications, 6(January), 113. https://doi.org/10.3389/fbioe.2018.00209

18. Lisdiyanti, P., Suyanto, E., Gusmawati, N. F., Ratnakomala, S., \& Fahrurrozi. (2011). Penerapan bakteri penghasil enzim urease untuk mengeraskan tanah berpasir.

19. Ng, W., Lee, M., \& Hii, S. (2012). An overview of the factors affecting microbial induced calcite precipitation and its potential application in soil improvement. Journal of Civil and Environmental Engineering, 6(2), 188-194.

20. Nurkhotimah, Yulianti, E., \& Rakhmawati, A. (2017). Pengaruh suhu dan $\mathrm{pH}$ terhadapa aktivitas enzim fosfatase bakteri termofilik sungai gendol pasca erupsi merapi. Jurnal Prodi Biologi, 6(8), 465-471.

21.Kumari, J. A., Rao, P. C., Padmaja, G., \& Madhavi, M. (2018). Effect of temperature on soil enzyme acid phosphatase. International Journal of Current Microbiology and Applied Sciences, $\quad 7(09), \quad$ 2830-2845. https://doi.org/10.20546/ijcmas.2018.709.352

22. Amri, E., Widhyastuti, N., \& Artika, I. M. (2010) Aktivitas amilase bakteri yang diisolasi dari sumber air panas Ciseeng Bogor. Sainstek, 2(1), 23-33.

23. Alam, M. S., Sarjono, P. R., \& Aminin, A. L. N. (2013). Isolasi dan karakteristik selulase dari bakteri selulolitik termofilik kompos pertanian desa bayat, klaten, Jawa Tengah. Sains Dan Matematika, 21(2), 48-53.

24. Tirkolaei, H. K., \& Bilsel, H. (2015). Statistical modeling of environmental factors on microbial urea hydrolysis process for biocement production. Advances in Material Science and Engineering, 2015, 14

25. Rahman, R. N. Z. A., Geok, L. P., Basri, M., \& Salleh, A. B. (2005). Physical factors affecting the production of organic solvent-tolerant protease by Pseudomonas aeruginosa strain K. Bioresource Technology, 96(4), 429-436. https://doi.org/10.1016/j.biortech.2004.06.012 